\title{
PENERAPAN MODEL PjBL PELAJARAN TEKNIK KERJA PERBENGKELAN UNTUK MENINGKATKAN HASIL BELAJAR SISWA XTAVI SMKN 3 SINGARAJA
}

\author{
B. K. Wirma Hendra ${ }^{1}$, G.R. P. Suka Arsa ${ }^{2}$, L. Krisnawati ${ }^{3}$ \\ 1,2Prodi Pendidikan Teknik Elektro, Universitas Pendidikan Ganesha, Singaraja \\ ${ }^{3}$ Prodi Teknik Elektronika, Universitas Pendidikan Ganesha, Singaraja \\ e-mail: wirma.hendra@yahoo.com, suka.arsa²@undiksha.ac.id, luh.krisnawati@undiksha.ac.id
}

\begin{abstract}
Abstrak
Penelitian ini bertujuan untuk meningkatkan hasil belajar siswa pada mata pelajaran Teknik Kerja Perbengkelan dengan penerapan model pembelajaran PjBL (Project Based Learning). Subjek penelitian ini adalah siswa kelas X TAV 1 SMK Negeri 3 Singarja, dengan jumlah siswa sebanyak 36 orang. Penelitian ini merupakan penelitian tindakan kelas yang dilaksanakan dalam dua siklus, dimana pada tiap siklusnya terdiri dari perencanaan, pelaksanaan, dan tindakan. Data yang diambil dalam penelitian ini mencakup data tentang hasil belajar siswa dari tiga ranah, yaitu: afektif, kognitif, dan psikomotor. Berdasarkan hasil tes siswa pada siklus I, diperoleh hasil belajar dengan rerata nilai 60,72 dan dengan siswa yang tuntas sebanyak 15 orang dan siswa yang belum tuntas sebanyak 21 orang. Pada siklus II, diperoleh hasil belajar dengan rerata nilai 78,44 dan dengan siswa yang tuntas sebanyak 32 orang dan siswa yang belum tuntas sebanyak 4 orang. Terjadi peningkatan pula pada ketuntasan klasikal dari 41,66 pada siklus I menjadi 88,88 pada siklus II.
\end{abstract}

Kata kunci: Project Based Learning, Hasil belajar

\section{Abstract}

This study aims to improve student learning outcomes on the subjects Working Technigue Workshop with Project Based Learning learning model application. The subjects were students of class $X$ TAV 1 SMK Negeri 3 Singaraja, with the number of students as many as 36 people. This research is a classroom action research conducted in two cycles, with each cycle consisting of planning, implementation, and action. Data taken in this study include data on student learning outcomes in three domains, namely affective, cognitive, and psychomotor. Based on the test results of students in the first cycle, the result of learning with a mean value of 60.72 and with students who have completed as many as 15 people and students who have not completed at least 21 people. In the second cycle,obtained the result of learning with a mean value of 78.44 and with students who have completed a total of 32 people and students who have not completed as many as four people. There was an increase also in the classical completeness of 41.66 in the first cycle to 88.88 in the second cycle.

Keywords: Project Based Learning, learning outcomes

\section{Pendahuluan}

Kegiatan belajar dalam keseluruhan proses pendidikan di sekolah merupakan kegiatan yang paling pokok. Pembelajaran berlangsung sebagai suatu proses saling mempengaruhi antara guru dan siswa. Dalam hal ini, kegiatan yang terjadi adalah guru mengajar dan siswa belajar. Ini berarti bahwa berhasil tidaknya pencapaian tujuan pendidikan, banyak bergantung pada proses yang dialami oleh siswa sebagai anak didik. Tujuan pendidikan di sekolah harus mampu mendukung kompetensi alumni, yaitu pengetahuan, nilai, sikap, dan kemampuan siswa untuk dapat mendekatkan dirinya dengan lingkungan, sosial, dan kebutuhan daerah, menurut Slameto (dalam Sanjaya, 2015: 1) 
Pembelajaran yang bermakna akan membawa siswa pada pengalaman belajar yang mengesankan. Pengalaman yang diperoleh siswa akan semakin berkesan apabila proses pembelajaran yang diperolehnya merupakan hasil dari pemahaman dan kreatif siswa sendiri. Proses pembelajaran yang berlangsung melibatkan siswa sepenuhnya untuk suatu kreatif sendiri. Keterlibatan guru hanya sebagai fasilitator dan moderator dalam proses pembelajaran tersebut. Untuk mencapai itu, pendidikan harus beradaptasi terhadap perubahan zaman. Dalam hal ini guru harus memperhatikan minat dan kemampuan siswa, serta bimbingan guru sangat diperlukan dalam peningkatan hasil belajar siswa. Disamping itu profesional guru dan minat siswa terhadap pelajaran merupakan faktor yang penting dalam meningkatkan hasil belajar siswa. Karena guru yang profesional dalam memberikan materi akan membangkitkan minat siswa dalam mengikuti pembelajaran.

Peran guru dalam proses pembelajaran, bukanlah mendominasi tetapi membimbing dan mengarahkan siswa untuk aktif memperoleh pemahamannya berdasarkan segala informasi yang siswa temukan dari lingkungannya. Keaktifan siswa merupakan salah satu prinsip utama dalam proses pembelajaran. Pengalaman belajar hanya dapat diperoleh jika siswa aktif berinteraksi dengan lingkungannya. Seorang guru dapat menyajikan dan menyediakan bahan pelajaran, tapi siswa yang mengolah dan mencernanya sendiri sesuai kemauan, kemampuan, bakat, dan latar belakangnya.

Sedangkan siswa belum terlibat secara aktif dalam pembelajaran. Secara umum, keaktifan siswa dalam pembelajaran tergolong rendah, hal ini terlihat dari siswa tidak banyak bertanya, aktivitas siswa terbatas pada mendengarkan, mencatat, dan menjawab pertanyaan bila guru memberi pertanyaan, siswa hadir di kelas dengan persiapan belajar yang tidak memadai, ribut jika diberi latihan, dan siswa hanya diam ketika ditanya sudah mengerti atau belum. Kenyataan ini belum menunjukkan ke arah pembelajaran yang bermakna. Sistem pembelajaran duduk tenang, mendengarkan informasi dari guru sepertinya sudah membudaya sejak dulu, sehingga untuk mengadakan perubahan ke arah pembelajaran yang aktif, kreatif, dan menyenangkan agak sulit.

Rendahnya keaktifan belajar siswa juga terlihat dalam pembelajaran Teknik Kerja Perbengkelan. Selama ini pembelajaran Teknik Kerja Perbengkelan harus memerlukan bimbingan kepada guru pengajar ke siswa dikarenakan kurangnya keaktifan belajar siswa sebab terfokus kepada guru. Untuk memahami, siswa harus aktif sehingga dapat mengembangkan kemampuannya dalam melakukan kegiatan pembelajaran dengan cara mengenal berbagai ide-ide dan seni yang ada di siswa, memahami konsep dan teori, serta berlatih memecahkan berbagai masalah yang terjadi pada siswa. Berdasarkan uraian diatas, maka peneliti memiliki peluang yang besar untuk menerapkan model pembelajaran PjBL (Project Based Learning) pada mata plajaran Teknik Kerja Perbengkelan di kelas X TAV 1 SMK Negeri 3 Singaraja untuk meningkatkan hasil blajar siswa pada tahun ajaran 2017/2018.

\section{Model Pembelajaran}

Strategi pembelajaran menurut Kemp (dalam Rusman, 2013: 132) adalah suatu kegiatan pembelajaran yang harus di kerjakan guru dan siswa agar tujuan pembelajaran dapat dicapai secara efektif dan efisien. Senada dengan pendapatnya Kemp, Dick and Cary (dalam Rusman, 2013: 132) juga menyebutkan bahwa strategi pembelajaran itu adalah suatu perangkat materi dan prosedur pembelajaran yang digunakan secara bersama-sama untuk menimbulkan hasil belajar pada peserta didik. Upaya mengimpletasikan rencana pembelajaran yang telah disusun dalam kegiatan nyata agar tujuan yang telah disusun dapat tercapai secara optimal, maka diperlukan suatu metode yang digunakan untuk merealisasikan strategis yang telah ditetapkan.

Dengan demikian, bisa terjadi satu strategis pembelajaran yang menggunakan beberapa metode, misalnya, untuk melaksanakan strategis ekspositori bisa digunakan metode ceramah sekaligus metode tanya jawab atau bahkan diskusi dengan memanfaatkan sumber daya yang tersedia termasuk menggunakan media pembelajaran. Oleh sebab itu, strategis berbeda dengan metode. Strategis menunjukan pada sebuah perencanaan untuk mencapai sesuatu, sedangkan metode adalah cara yang dapat digunakan untuk melaksanakan strategis. Dengan kata lain, strategis adalah a plan off operation 
achieving something; sedangkan metode adalah a way in achieving something.

\section{Model Pembelajaran Project Based Learning}

Model pembelajaran ini secara bahasa diartikan sebagai model yang menekankan pada pengadaan proyek atau kegiatan penelitian kecil dalam penelitian. Menurut CORD dkk (dalam Fathurrohman, 2016: 117-118) menyatakan sebagaimana juga dikutip Made Wena, Pembelajaran berbasis proyek adalah sebuah model pembelajaran yang inovatif dan lebih menekankan pada belajar kontekstual melalui kegiatan-kegiatan yang kompleks.

Buck Institute for Education (dalam Sutirman, 2013: 43) menyatakan bahwa pembelajaran berbasis proyek adalah "suatu metode pengajaran sistematis yang melibatkan para siswa dalam mempelajari pengetahuan dan keterampilan melalui proses yang terstruktur, pengamalan nyata dan teliti yang merancang untuk menghasilkan produk.

Berpijak dari definisi di atas, dapat di pahami bahwa Pembelajaran Berbasis Proyek merupakan model pembelajaran yang menggunakan proyek atau kegiatan sebagai sarana pembelajaan untuk mencapai kompetisi sikap, peserta didik untuk memecahkan masalah dengan menerapkan keterampilan meneliti, menganalisis, membuat, hingga mempresentasikan produk pembelajaran berdasarkan pengalaman nyata. Model pembelajaran ini memperkenankan peserta didik untuk bekerja secara mandiri maupun berkelompok dalam menkonstruksikan produk autentik yang bersumber dari masalah nyata dalam kehidupan sehari-hari.

Sebagai sebuah model pembelajaran, menurut Thomas (dalam Fathurrohman, 2016: 121-122) pembelajaran berbasis proyek memiliki beberapa prinsip sebagai berikut.

1. Prinsip sentralistis (centrality), menegaskan bahwa kerja proyek merupakan esensi dari kurikulum. Model ini merupakan pusat strategi pembelajaran, diman peserta didik belajar konsep utama dari suatu pengetahuan melalui kerja proyek. Oleh karena itu, kerja proyek bukan merupakan praktik tambahan dan aplikasi praktis dari konsep yang sedang dipelajarin, melainkan menjadi sentral kegiatan pembelajaran dikelas.

2. Prinsip pertanyaan penuntun (driving question), berarti bahwa kerja proyek berfokus pada pertanyaan atau permasalahan yang dapat mendorong peserta didik untuk berjuang memperoleh konsep atau prinsip utama.

3. Prinset investigasi konstruktif (constructive investigation) merupakan proses yang mengarah kepada pencapaian tujuan, yang mengandung kegiatan inkuiri, pembangunan konsep dan resolusi. Penentuan proyek haruslah dapat mendorong peserta didik untuk mengkonstruksi pengetahuan sendiri untuk memecahkan persoalan yang dihadapinya. Dalam hal ini guru harus mampu merancang suatu proyek yang mampu menumbuhkan rasa ingin meneliti, rasa untuk berusaha memecahkan masalah, dan rasa ingin tahu yang tinggi.

4. Prinsip otonomi (autonomy) dalam pembelajaran berbasis proyek dapat diartikan sebagai kemandirian peserta didik dalam melaksanakan proses pembelajaran, yaitu bebas menentukan pilihannya sendiri, bekerja dengan minimal mengawasi, dan bertanggung jawab. Oleh karena itu, lembar kerja peserta didik, petunjuk kerja praktikum, dan sejenisnya bukan merupakan aplikasi dari PjBL (Project Based Learning). Dalam hal ini guru hanya berperan sebagai fasilitator dan motivator untuk mendorong tumbuhnya kemandirian peserta didik.

Prinsip realistis (realism) berarti bahwa proyek merupakan suatu yang nyata. PjBL harus dapat memberikan perasaan realistis kepada peserta didik dan mengandung tantangan nyata yang berfokus pada permasalahan autentik, tidak dibuat-buat, dan solusinya dapat diimplementasikan di lapangan.

\section{Pengertian Belajar dan Pembelajaran}

Belajar adalah proses perubahan tingkah laku individu sebagai hasil dari pengalamannya dalam berinteraksi dengan lingkungan. Belajar bukan hanya sekedar menghafal, melainkan suatu proses mental yang terjadi pada diri seseorang. 
Pembelajaran pada hakikatnya merupakan suatu proses interaksi antara guru dengan siswa, baik interaksi secara langsung seperti kegiatan tatap muka maupun secara tidak langsung, yaitu dengan menggunakan berbagai media pembelajaran. Didasari oleh adanya perbedaan interaksi tersebut, maka pembelajaran dapat dilakukan dengan menggunakan berbagai pola pembelajaran.

\section{Hasil Belajar}

Menurut Nana Sudjana (2016: 22) dalam sistem pendidikan nasional rumusan tujuan pendidikan, baik tujuan kurikuler maupun tujuan instruksiunal, menggunakan klasifikasi hasil belajar dari Benyamin Bloom yang secara garis besar membaginya menjadi tiga ranah, yakni ranah kongnitif, ranah afektif, dan ranah psikomotoris.

Menurut Purwanto (2014: 48) domain hasil belajar adalah perilaku-perilaku kejiwaan yang akan diubah dalam proses pendidikan. Perilaku kejiwaan itu dibagi dalam tiga domain: kongnitif, afektif dan pasikomotor. Ketiga ranah tersebut dijelaskan sebagai berikut.

\section{Hasil Belajar Kognitif}

Hasil belajar kognitif adalah perubahan perilaku yang terjadi dalam kawasan kognisi. Proses belajar yang melibatkan kognisi meliputi kegiatan sejak dari penerimaan stimulus eksternal oleh sensor, penyimpanan dan pengolahan otak menjadi informasi hingga pemanggilan informasi ketika diperlukan untuk menyelesaikan masalah. Oleh karena belajar melibatkan otak maka perubahan perilaku akibatnya juga terjadi dalam otak berupa kemampuan tertentu oleh otak untuk menyelesaikan masalah.

Hasil belajar kognitif tidak merupakan kemampuan tunggal. Kemampuan yang menimbulkan perubahan perilaku dalam domain kognitif meliputi beberapa tingkatan atau jenjang. Bloom membagi dan menyusun secara hirakhis tingkat hasil belajar kognitif mulai dari yang paling rendah dan sederhana, yaitu hafalan sampai yang paling tinggi dan kompleks, yaitu evaluasi. Makin tinggi tingkat, maka makin kompleks dan penguasaan suatu tingkat mempersyaratkan penguasaan tingkat sebelumnya. Enam tingkat itu adalah hafalan (C1), pemahaman (C2), penerapan (C3), analisis (C4), sintesis (C5), dan evaluasi (C6).

Kemampuan menghafal (knowledge) merupakan kemampuan kognitif yang paling rendah. Kemampuan ini merupakan kemampuan memanggil kembali fakta yang disimpan dalam otak digunakan untuk merespons suatu masalah. Dalam kemampuan tingkat ini fakta dipanggil kembali persis, seperti ketika disimpan. Misalnya hari proklamasi kemerdekaan Republik Indonesia adalah 17 Agustus.

Kemampuan pemahaman (comprehension) adalah kemampuan untuk melihat hubungan fakta dengan fakta. Menghafal fakta tidak lagi cukup karena pemahaman menuntut pengetahuan akan fakta dan hubungannya. Misalnya memahami proses terjadinya hujan. Kemampuan penerapan (application) adalah kemampuan kognitif untuk memahami aturan, hukum, rumus dan sebagainya dan menggunakan untuk memecahkan masalah. Misalnya sebuah bak air dengan panjang 2 meter, lebar 1,5 meter dan tinggi 1 meter, berapa volume yang dapat dimuat? Kemampuan analisis (analysis) adalah kemampuan memahami sesuatu dengan menguraikannya ke dalam unsur-unsur. Kemampuan sintesis (synthesis) adalahkemampuan memahami dengan mengorganisasikan bagian-bagian ke dalam kesatuan. Kemampuan evaluasi (evaluation) adalah kemampuan membuat penilaian dan mengambil keputusan dari hasil penilaiannya.

\section{Hasil Belajar Afektif}

Tingkah laku afektif adalah tingkah laku yang menyangkut keanekaragaman perasaan seperti: takut, marah, sedih, gembira, kecewa, senang, benci, was-was, dan sebagainya. Tingkah laku seperti ini tidak terlepas dari pengaruh pengalaman belajar. Oleh karena itu juga dapat dianggap sebagai perwujudan perilaku belajar.

Komponen afektif merupakan keyakinan individu dan penghayatan orang tersebut tentang objek sikap apakah ia merasa senang atau tidak senang, bahagia atau tidak bahagia. Sikap mempunyai tiga karakteristik: 
1) Intensitas, yaitu kekuatan perasaan terhadap objek;

2) Arah terhadap objek apakah positif, negatif atau netral;

3) Target merupakan sasaran sikap, terhadap apa sikap ditunjukan.

\section{Hasil Belajar Psikomotor}

Beberapa ahli mengklasifikasikan dan menyusun hirarhi hasil belajar psikomotor. Hasil belajar disusun dalam urutan mulai dari yang paling rendah dan sederhana sampai yang paling tinggi dan kompleks. Hasil belajar tingkat yang lebih tinggi hanya dapat dicapai apabila siswa telah menguasai hasil belajar yang lebih rendah. Menurut Harrow hasil belajar psikomotor dapat diklasifikasikan menjadi enam, yaitu gerakan reflex, gerakan fundamental dasar, kemampuan perseptual, kemampuan, gerakan keterampilan, dan komunikasi tanpa kata.

Presepsi (perception) adalah kemampuan hasil belajar psikomotorik yang paling rendah. Persepsi adalah kemampuan membedakan suatu gejala dengan gejala yang lain. Kesiapan (set) adalah kemampuan menempatkan diri untuk memulai suatu gerakan. Misalnya, kesiapan menempatkan diri sebelum lari, menari, mengetik, memeragakan, mendemonstrasikan penggunaan thermometer dan sebagainya. Gerakan terbimbing (guided response) adalah kemampuan melakukan gerakan meniru model yang dicontohkan. Gerakan terbiasa (mechanisme) adalah kemampuan melakukan gerakan tanpa ada model contoh. Kemampuan dicapai karena ada latihan berulang-ulang sehingga menjadi kebiasaan. Gerakan kompleks (adaptation) adalah kemampuan melakukan serangkaian gerakan dengan cara, urutan, dan irama yang tepat. Kreativitas (origination) adalah kemampuan menciptakan gerakan-gerakan baru yang tidak ada sebelumnya atau mengombinasikan gerakan-gerakan yang ada menjadi kombinasi gerakan baru yang orisinil

\section{Metode}

Menurut Kardiawarman, (dalam paizaluddin dan ermalinda 2014:2) penelitian tindakan kelas berasal dari bahasa inggris Classroom Action Research, yang berarti penelitian yang dilakukan pada sebuah kelas untuk mengetahui akibat tindakan yang diterapkan pada suatu subyek penelitian di kelas tersebut.

Secara lebih luas penelitian tindakan diartikan sebagai penelitian yang berorientasi pada penerapan tindakan dengan tujuan peningkatan mutu atau pemecahan pada sekelompok subyek yang diteliti dan mengamati tingkat keberhasilan atau akibat tindakannya, untuk kemudian diberikan tindakan lanjutan yang bersifat penyempurnaan tindakan atau penyesuaian dengan kondisi dan situasi sehingga diperoleh hasil yang lebih baik. Tindakan yang secara sengaja diberikan tersebut diberikan oleh guru atau berdasarkan arahan guru yang kemudian dilakukan oleh siswa. Konteks pekerjaan guru makan penelitian tindakan yang dilakukan Penelitian Tindakan Kelas, Suharsimi (dalam Paizaluddin dan Ermalinda 2014: 7). Dengan demikian Penelitian Tindakan Kelas Suatu kegiatan penelitian dengan mencermati sebuah kegiatan belajar yang diberikan tindakan, yang secara sengaja dimuculkan dalam sebuah kelas, yang bertujuan memecahkan masalah atau meningkatkan mutu pembelajaran di kelas tersebut. Tindakan yang secara sengaja dimunculkan.

Penelitian ini merupakan jenis penelitian tindakan kelas yang dilakukan oleh guru di dalam kelas, dengan tujuan untuk meningkatkan hasil belajar siswa keas X TAV 1 di SMK Negeri 3 Singaraja dalam pembelajaran Teknik Perbengkelan dengan Model Project Based Learning (PjBL). Penelitian ini terdiri dari dua siklus. Siklus I meliputi kegiatan perencanaan, pelaksanaan dan pengamatan, serta refleksi. Siklus II sama dengan siklus I, namun dalam pelaksanaanya meninjau dari hasil refleksi pada siklus I. Menurut Suharsimi Arikunto (dalam Paizaluddin dan Ermalinda, 2014: 34) adapun model dan penjelasan untuk masing-masing tahap adalah sebagai berikut: 


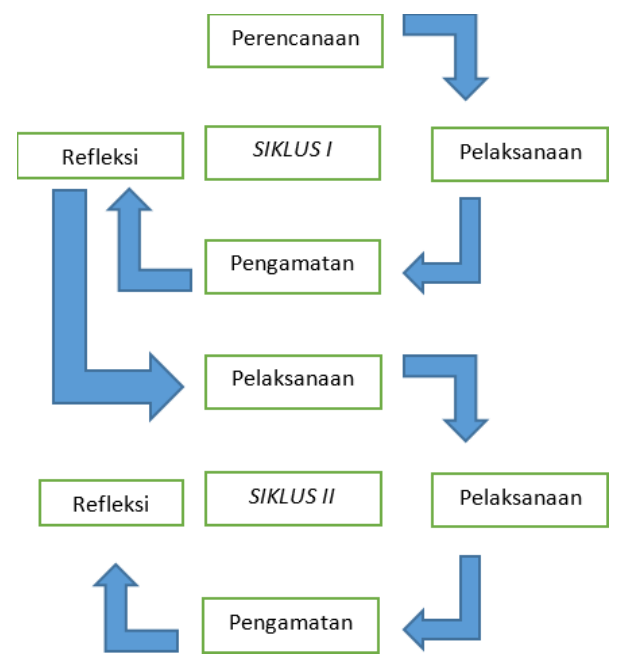

Gambar. 1 Prosedur Penelitian Tindakan

(Sumber : Suharsimin Arikunto, 2006: 17-12)

1) Perencanaan atau Rancangan Tindakan

Dalam tahap ini peneliti menjelaskan tentang apa, mengapa, kapan, dimana, oleh siapa dan bagaimana tindakan tersebut dilakukan. Penelitian tindakan yang ideal sebetulnya dilakukan secara berpasangan antara pihak yang melakukan tindakan dan pihak yang mengamati proses jalannya tindakan.

2) Pelaksanaan Tindakan

Tahap ke-2 dari penelitian tindakan adalah pelaksanaan yang merupakanimplementasi atau penerapan isi rancangan, yaitu mengenakan tindakan di kelas

3) Pengamatan

Tahap ke-3, yaitu kegiatan pengamatan yang dilakukan oleh pengamat. Sebetulnya sedikit kurang tepat kalau pengamatan ini dipisahkan dengan pelaksanaan tindakan karena seharusnya pengamatan dilakukan pada waktu tindakan dilakukan. Sebutan tahap ke-2 diberikan untuk memberikan peluang kepada guru pelaksanaan yang juga berstatus sebagai pengamat.

4) Refleksi

Tahap ke-4 merupakan kegiatan untuk mengemukakan kembali apa yang sudah dilakukan. Istilah refleksi berasal dari kata bahasa Inggris reflection yang diterjemahkan dalam bahasa Indonesia pemantulan. Kegiatan refleksi ini sangat tepat dilakukan ketika guru pelaksana sudah selesai melakukan tindakan

Jadi penelitian tindakan berkolaborasi dilakukan dengan cara bekerjasama, dengan ketentuan sebagai berikut.

1. Menyusun perencanaan bersama-sama.

2. Saling bergantian mengamati proses waktu pelaksanaan.

3. Saling mengikuti kelas teman waktu refleksi.

4. Menyusun laporan sendiri-sendiri.

Dilaporkan dengan judul yang sama, dijelaskan model yang dilaksanakan dalam berkolaborasi.

\section{SIKLUS I}

\section{Tahap Perencanaan}

Pada tahap ini peneliti bersama guru pengajar menyusun rancangan tindakan sebagai acuan dalam pelaksanaan tindakan sebagai berikut. 
a. Menganalisis silabus tentang materi yang akan dipelajari siswa pada pelaksanaan tindakan siklus I.

b. Menjabarkan materi pembelajaran menjadi sub-sub materi sesuai dengan pedoman Kurikulum 2013.

c. Merumuskan indikator hasil belajar, sebagai pembatasan tentang apa yang diharapkan dapat dipahami siswa setelah mengikuti pembelajaran yang didasarkan pada standar kompetensi mata pelajaran.

d. Menyusun Rencana Pelaksanaan Pembelajaran (RPP).

e. Menyiapkan media pembelajaran Project Based Learning.

Sebelum pelaksanaan tindakan I, dilakukan orientasi awal dan pengenalan terhadap rencana penerapan Model Project Based Learnin

\section{Tahap Pelaksanaan}

Guru atau peneliti melaksanakan rencana pelaksanaan pembelajaran yang telah disusun dan disiapkan sebelumnya yang telah disesuaikan dengan metode Project Based Learning $(\mathrm{PjBL})$. Saat proses belajar berlangsung, peneliti atau guru sekaligus mengamati aktivitas siswa dalam mengikuti proses belajar dengan menggunakan sarana yang dipersiapkan sebelumnya.

Selanjutnya guru mengevaluasi hasil belajar melalui pemberian tes tulis tentang materi yang dipelajari dan juga melakukan penelitian terhadap prestasi hasil kerja masing-masing kelompok dan setelah pelaksanaan tes, guru memeriksa hasil kerja siswa dan diberikan angka rentang 0-100. Adapun penjabaran pertemuan saat melakukan proses penelitian didalam kelas adalah sebagai berikut.

1. Mempersiapkan semua perangkat pembelajaran yang akan digunakan dalam kelas termasuk mempersiapkan permasalahan yang akan diberikan ke siswa.

2. Menyampaikan materi secara singkat dengan model Project Based Learning.

3. Memberikan pertanyaan kepada siswa apakah siswa sudah memahami dan mengerti tentang materi yang disampaikan. (dapat ditandai dengan siswa mampu bertanya, menjawab dan berpendapat).

4. Guru meminta siswa untuk memikirkan suatu topik, dengan siswa lain dan mendiskusikan, kemudian berbagi ide dengan seluruh kelas mengenai materi dan masalah yang sudah di dapatkan oleh siswa.

5. Setelah mendapatkan masalah dari masing-masing siswa, guru membantu siswa mendefinisikan dan mengorganisasikan proyek yang akan dilakukan.

\section{Pertemuan I/Siklus I}

Pada pertemuan I siklus I, kegiatan yang dilakukan adalah menyampaikan sub materi, yaitu Sistem pengelolaan alat dan peralatan (tool \& Equiptment Managemen) dan kebutuhan bahan praktik sebagai data base asset. Kegiatan ini dilakukan selama 4 jam pelajaran, yaitu 240 menit.

\section{Pertemuan II/Siklus I}

Pada pertemuan II siklus I, kegiatan yang dilakukan adalah menyampaikan sub materi, yaitu Pengelompokan alat dan peralatan bengkel. Kegiatan ini dilakukan selama 4 jam pelajaran, yaitu 240 menit.

\section{Pertemuan III /Siklus I}

Pada pertemuan III siklus I hanya diadakan tes tulis secara individu kepada seluruh siswa kelas X TAV 1 SMK N 3 Singaraja, yang dilakukan selama 4 jam pelajaran, yaitu 240 menit.

Mengumpulkan hasil penilaian siswa yang berupa hasil kegiatan siswa selama proses pembelajaran, seperti hasil tes akhir siklus. 


\section{Tahap Observasi/Evaluasi}

Pengamatan yang dilakukan adalah pengamatan pada aktivitas siswa. Pengamatan ini dilakukan oleh guru beserta yang melakukan penelitian di kelas X TAV 1 dengan mata pelajaran Teknik Kerja Perbengkelan untuk menentukan tingkat keberhasilan dari siklus I.

\section{Tahap Refleksi}

Refleksi dimaksudkan untuk melihat apakah rencana telah terlaksana secara optimal atau perlu dilakukan perbaikan. Refleksi dilakukan pada setiap akhir pembelajaran dan akhir siklus. Sebagai dasar refleksi pada setiap akhir pembelajaran adalah kendala-kendala yang dialami siswa dalam pemahaman materi yang disampaikan pada pembelajaran Teknik Kerja Perbengkelan. Hasil-hasil refleksi tersebut selanjutnya digunakan sebagai bahan pertimbangan atau penyempurnaan tahapan-tahapan pada siklus II.

\section{SIKLUS II}

Pelaksanaan tindakan siklus II berdasarkan hasil refleksi dari siklus I. Apabila pada siklus I masih ditemukan kelemahan dalam penerapan model Project Based Learning (PjBL) dengan asesmen autentik pada pelajaran teknik perbengkelan, maka akan dilanjutkan pelaksanaan siklus II.

a. Mempersiapkan sarana dan prasarana yang diperlukan dalam proses pembelajaran. Sarana dan prasarana yang perlu dipersiapkan adalah alat yang akan digunakan untuk melakukan pembelajaran dihadapan siswa.

b. Melaksanakan kegiatan pembelajaran berdasarkan prosedur pemakaian model Project Based Learning (PjBL).

Adapun penjabaran pertemuan saat melakukan proses penelitian di dalam kelas adalah sebagai berikut.

1. Mempersiapkan semua perangkat pembelajaran yang akan digunakan dalam kelas termasuk mempersiapkan permasalahan yang akan diberikan ke siswa.

2. Menyampaikan materi secara singkat dengan model Project Based Learning.

3. Memberikan pertanyaan kepada siswa apakah siswa sudah memahami dan mengerti tentang materi yang disampaikan. (dapat ditandai dengan siswa mampu bertanya, menjawab dan berpendapat).

4. Guru meminta siswa untuk memikirkan suatu topik, dengan siswa lain dan mendiskusikan, kemudian berbagi ide dengan seluruh kelas mengenai materi dan masalah yang sudah didapatkan oleh siswa.

Setelah mendapatkan masalah dari masing-masing siswa, guru membantu siswa mendefinisikan dan mengorganisasikan proyek yang akan dilakukan

\section{Pertemuan I/Siklus II}

Pada pertemuan I siklus II, kegiatan yang dilakukan adalah sama, seperti pada pertemuan I siklus I hanya sub materi yang disampaikan berbeda, yaitu macam-macam simbol kategori sumber tegangan dan macam-macam simbol kategori konektor. Kegiatan ini dilakukan selama 4 jam pelajaran, yaitu 240 menit.

\section{Pertemuan II/Siklus II}

Pada pertemuan II siklus II, kegiatan yang dilakukan adalah sama, seperti pada pertemuan I siklus I hanya sub materi yang disampaikan berbeda, yaitu macam-macam simbol kategori komponen masukan, macam-macam simbol kategori komponen keluaran dan macam-macam simbol kategori komponen aktif dan pasif. Kegiatan ini dilakukan selama 4 jam pelajaran, yaitu 240 menit.

\section{Pertemuan III/Siklus II}


Pada pertemuan III siklus II hanya diadakan tes akhir belajar secara individu kepada seluruh siswa kelas X TAV 1 SMK Negeri 3 Singaraja yang dilakukan selama 4 jam pelajaran.

Mengumpulkan hasil penilaian siswa yang berupa hasil kegiatan siswa selama proses pembelajaran, seperti hasil tes akhir siklus.

\section{Tahap Evaluasi II}

Melakukan evaluasi siswa selama berlangsung proses belajar mengajar dengan menggunakan test belajar untuk melihat adanya peningkatan hasil belajar siswa.

a. Mengevaluasi hasil tes belajar siswa yang dilakukan pada siklus II, untuk dilakukan tindak lanjut berupa penilaian dan balikan kepada siswa.

b. Mengevaluasi proses pembelajaran melalui penerapan model Project Based Learning, yang meliputi kendala-kendala serta kesulitan yang ditemukan selama pelaksanaan tindakan II.

\section{Tahap Refleksi II}

Refleksi dilakukan pada setiap akhir pembelajaran dan akhir siklus. Dasar refleksi adalah hasil tes akhir siklus II, dan hasil belajar serta wawancara dengan siswa terhadap kesulitankesulitan belajar yang dialami dalam proses pembelajaran serta kendala-kendala yang ditemukan siswa selama pelaksanaan pembelajaran. Hasil refleksi ini digunakan sebagai dasar untuk menyusun rekomendasi dari penelitian ini. Rekomendasi yang diberikan berupa analisis mengenai kebaikan, kekurangan dan peluang penerapan pembelajaran model Project Based Learning dalam proses pembelajaran di kelas khususnya untuk mata pelajaran Teknik Perbengkelan.

\section{Hasil dan Pembahasan}

Berdasarkan hasil analisis data, diperoleh rerata hasil belajar siswa untuk refleksi awal, siklus I dan siklus II, seperti yang terlihat pada grafik. 2.

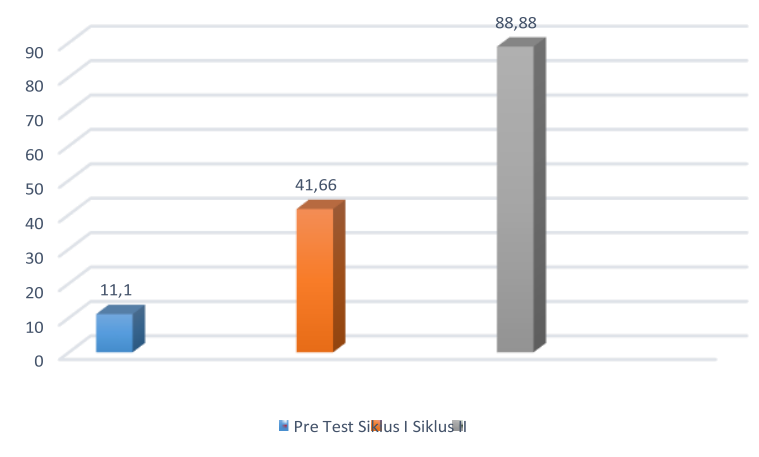

Grafik. 2 Perbandingan Hasil Belajar Refleksi Awal, Siklus I dan Siklus II 
Tabel. 1 Peningkatan Hasil Belajar siswa dari Pre test, Siklus I, Siklus II

\begin{tabular}{cccccccc}
\hline Hasil & $\begin{array}{c}\text { Jumlah } \\
\text { Siswa }\end{array}$ & KKM & \multirow{2}{*}{$\begin{array}{c}\text { Jumlah } \\
\text { Nilai }\end{array}$} & Rata-rata & $\begin{array}{c}\text { Ketuntasan } \\
\text { Klasikal }\end{array}$ & Tuntas & $\begin{array}{c}\text { Tidak } \\
\text { Tuntas }\end{array}$ \\
\hline Pre test & 36 & 75 & 1735 & 10,83 & $1,1 \%$ & 4 & 32 \\
\hline Siklus I & 36 & 75 & 2615 & 60,72 & $41,66 \%$ & 15 & 21 \\
\hline Siklus II & 36 & 75 & 2820 & 78,33 & $88,88 \%$ & 32 & 4 \\
\hline
\end{tabular}

Berdasarkan data pada Table. 1, didapat bahwa dari 36 orang siswa yang mengikuti evaluasi siklus I diperoleh jumlah nilai 2615 dengan nilai rata-rata 60,72 dengan siswa yang tuntas pada siklus 1 , sebanyak 15 orang siswa dan siswa yang tidak tuntas sebanyak 21 orang, sehingga diperoleh ketuntasan klasikal sebesar 41,66 \%. Setelah perbaikan pada siklus II melalui penerapan model pembelajaran ( Project Based Learning) terjadi peningkatan jumlah nilai dan rata-rata siklus II diperoleh sebesar 2820 dan 78,33, selain itu jumlah siswa yang tuntas pada siklus I juga mengalami peningkatan sebanyak 17 orang, yaitu dari 15 orang pada siklus I menjadi 32 orang pada siklus II. Sedangkan, siswa yang belum tuntas mengalami penurunan sebanyak 17 orang dari siklus I 21 orang menjadi 4 orang pada siklus II.

Ketuntasan hasil belajar siswa kelas X TAV 1 dengan penerapan model pembelajaran PjBL ( Project Based Learning) diperoleh sebanyak 32 orang atau $88,88 \%$ siswa tuntas dengan nilai diatas KKM (75). Karena target yang ingin dicapai dalam penelitian tindakan kelas ini, yaitu ketuntasan hasil belajar atau ketuntasan klasikalnya $85 \%$, maka dari itu penelitian ini dapat dihentikan karena sudah mencapai target yang ingin dicapai, maka penelitian ini bisa dikatakan selesai sampai di siklus II, karena sudah mencapai keberhasilan dalam penelitian.

\section{Simpulan dan Saran}

Berdasarkan hasil penelitian dan analisis hasil penelitian maka dapat disimpulkan bahwa Penerapan model pembelajaran PjBL (Project Based Learning) dapat meningkatkan hasil belajar mata pelajaran Teknik Kerja Perbengkelan pada siswa kelas X TAV 1 SMK Negeri 3 Singaraja. Hal ini dapat dilihat dari penelitian yang sudah dilakukan dengan tahapan perencanaan, pelaksanaan, observasi/evaluasi, dan refleksi. Peningkatan hasil belajar setelah diterapkan model pembelajaran PjBL (Project Based Learning) dapat dilihat dari rata-rata hasil belajar yang meningkat dari 60,72 pada siklus I menjadi sebesar 78,33 pada siklus II. Ketuntasan belajar klasikal juga meningkat dari $41,66 \%$ pada siklus I menjadi sebesar 88,88 $\%$ pada siklus II.

\section{Daftar Pustaka}

Fathurrohman, Muhammad. 2016. Model-model Pembelajaran Inovatif Alternatif Desain Pembelajaran yang Menyenangkan. Jogjakarta: Ar-Ruzz Media.

Paizaluddin dan Ermalinda. 2014. Penelitian Tindakan Kelas (Classroom Action Research) Panduan Teoritis dan Praktis. Bandung: Alfabeta.

Purwanto. 2014. Evaluasi Hasil Belajar. Yogyakarta: Pustaka Pelajar.

Rusman. 2013. Model-model Pembelajaran Mengembangkan Profesionalisme Guru. Edisi Ke2. Jakarta: Rajawali Pers.

Sanjaya, Dewa Komang. 2015. Penerapan Model Pembelajaran Kooperatif Tipe Tps (ThinkPair-Share) Untuk Meningkatkan Hasil Belajar Siswa Pada Mata Pelajaran Prakarya Dan Kewirausahaan Di Kelas Xi Mia4 Sma Negeri 1 Singaraja. Sekrpsi (Tidak Di Terbitkan). Universitas Pendidikan Ganesha.

Sudjana, Nana. 2016. Penilaian Hasil Proses Belajar Mengajar. Bandung: PT. Remaja Rosda Karya. 
Jurnal Pendidikan Teknik Elektro Undiksha

Vol. 6 No. 2, Agustus 2017

ISSN: 2599-1531

Sutirman. 2013. Model-model Pembelajaran Inovatif. Yogyakarta: Graha IImu. 